\title{
A Qualitative Study of Time Overrun of Completed Road Projects Awarded by the Niger Delta Development Commission in the Niger Delta Region of Nigeria
}

\author{
Ogbeide F. N. ${ }^{1}{ }^{*}$, Ehiorobo J. O. ${ }^{2}$, Izinyon O. C. ${ }^{3}$ and Ilaboya I. R. ${ }^{4}$ \\ ${ }^{1}$ Utilities, Infrastructural Development \& Waterways, NDDC Port Harcourt, Nigeria \\ ${ }^{2,3,4}$ Department of Civil Engineering, University of Benin, Benin City, Edo State, Nigeria \\ Corresponding Author: *nosakhderick@yahoo.com
}

https://doi.org/10.36263/nijest.2021.01.0269

\begin{abstract}
Time overrun of completed road projects awarded by the Niger Delta Development Commission (NDDC) in the Niger Delta Region of Nigeria from its inception in 2000 up to 2015 was studied. Out of 3315 roads awarded, only 1081 roads representing 31.65 percent were completed within the review period. The qualitative study was carried out on randomly selected completed 162 road projects for analysis, and a conceptual model of time series was developed. In developing the regression model, both dependent and independent variables were subjected to normality tests assessed by skewness coefficient, kurtosis value, Jarque-Bera test, residual probability plot, heteroscedasticity test and the variance inflation factor. Also, with knowledge of total road projects awarded by the Commission, it is now possible to predict proportions of roads experiencing schedule overruns.
\end{abstract}

Keywords: Construction delays, Time overrun, Qualitative studies, Inflation factor

\subsection{Introduction}

Schedule control is the main key to a successful project (Pall et al., 2016). A construction project is acknowledged as successful when the aim of the project is achieved in terms of the predetermined objectives of the completed projects which include completing the projects on time, within budget and desired quality in accordance with the specifications, as well as to stakeholder's satisfaction (Owolabi et al., 2014; Khan, 2015). Time overruns give negative impressions on the project and all the involved construction parties. Ramli et al. (2018) asserted that when this happens, the overall project performance will decrease and competency of involved workers and professionals will be doubtful.

Delay is one of the numerous challenges of construction worldwide. The others include cost overrun, construction waste, poor safety, poor quality, excessive resource consumption and threat to environment (Memon et al., 2014). Although scientific and engineering tools have been applied to improve construction process, the complex nature of road construction projects still makes construction delays inevitable.

Fregenti and Cominios (2012) defined construction delay as time lag in completion of activities from its specified time in the contract but, Mohamad (2010) defined construction delay as an act or event that extend the time to complete or perform an act under the contract. Pickavance (2010) refers to construction delay as something happening at a late time than planned, expected, specified in a contract or beyond the date the parties agreed upon for the delivery of a project, Kolhe and Darade (2014) conceptualized delay to mean loss of revenue to the owner through lack of production facilities and rent-able space or a dependence on present facilities. While all above studies and many more theorize construction delay essentially in terms of time overruns that go beyond agreed date, Lo et al. (2006) however, introduced a different view of delay, in which the progress of work has not entirely stopped but has slowed down. The perception emphasises the slowing of progress, in contrast with the generally held view of postponement and stoppage of work. Another closely related concept of construction delay is construction disruption which Kikwasi (2012) defined as events that disturb the 
construction programme and interferes with the flow of work in the project. Chai et al. (2015) also introduced the concept of sick projects defined as projects that results from delay with extensive critical delays, leading to abandonment. A simple pictorial illustration of the concept of construction delay as depicted by Chai et al. (2015) is shown in Figure 1.

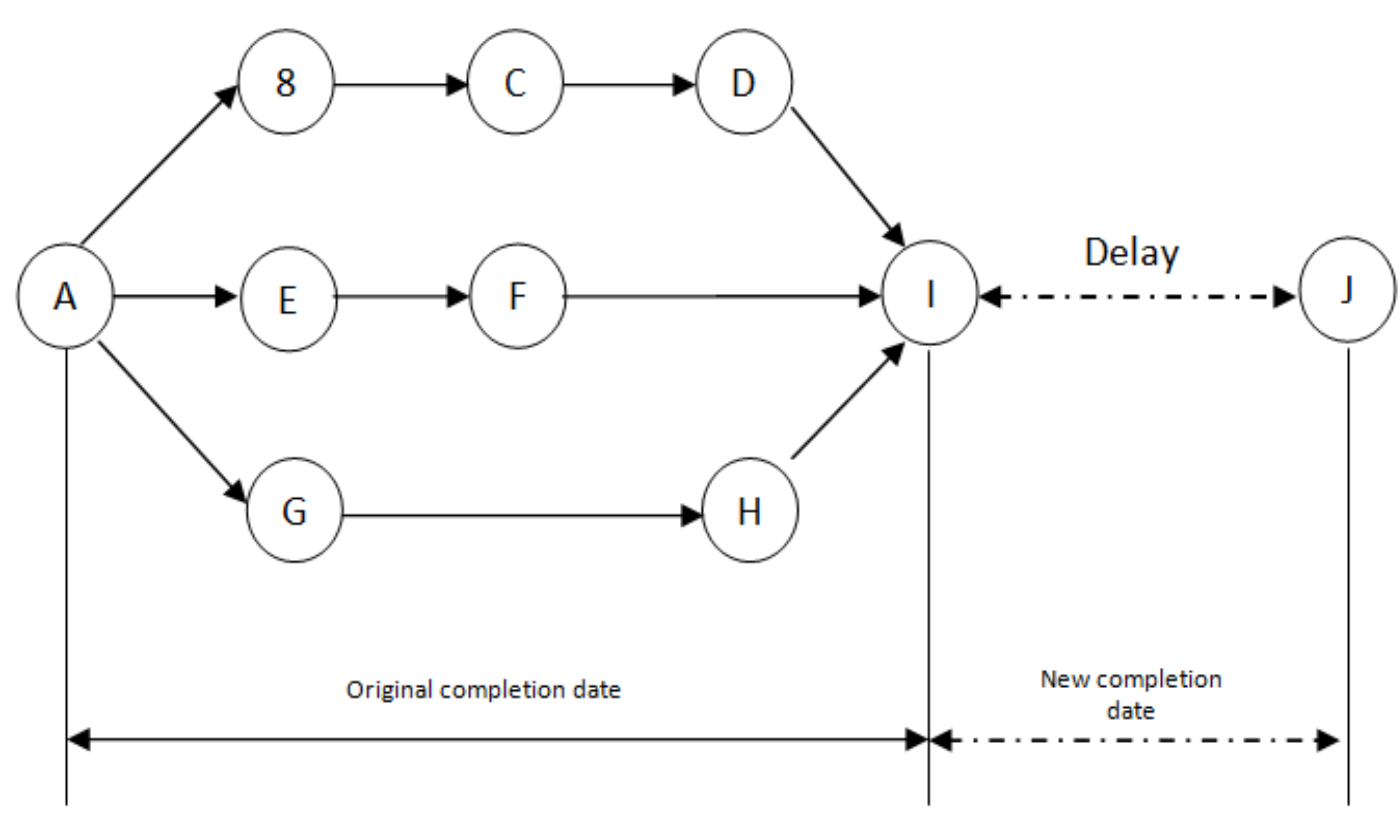

Figure 1: Philosophy of delay in the construction industry (Chai et al., 2015)

The major challenges when prescribing solutions of handling delay problems in construction processes have been magnitude and size, availability of fund, environment, organisational structure, etc. One of such scientific process introduced by Fregenti and Cominios (2012) rests on the cumulative aggregation of the principles of STEEPOL, GRC and MEDIC in achieving a strategically planned project:

\section{STEEPOL}

$\mathrm{S}=$ Social

$\mathrm{T}=$ Technology

$\mathrm{E}=$ Environmental

$\mathrm{E}=$ Economic

$\mathrm{P}=$ Political

$\mathrm{O}=$ Organisation

$\mathrm{L}=$ Legal

\section{GRC}

$\mathrm{G}=$ Governance, mandate, ethics

$\mathrm{R}=$ Risk

$\mathrm{C}=$ Compliance, standards, specifications
MEDIC
$M=$ Maintain
$E=$ Eliminate
$D=$ Decrease
$\mathrm{I}=$ Increase
$\mathrm{C}=$ Create

Duerkop and Hurt (2017) also proposed a PESTLE (Political, Economic, Social, Technological, Legal and Environmental) model in assuring that critical infrastructure are delivered to time and cost. Fregenti and Comninos (2012) identified four variables as critical factorial determinants of a successful project as shown in Figure 2.

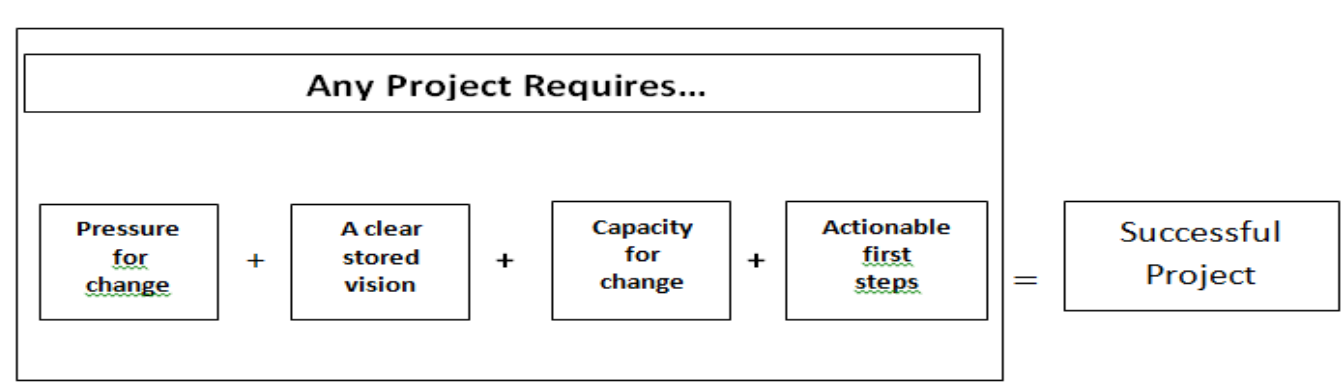

Figure 2a: Success factors for project implementation Source: Fregenti and Cominios (2012) 


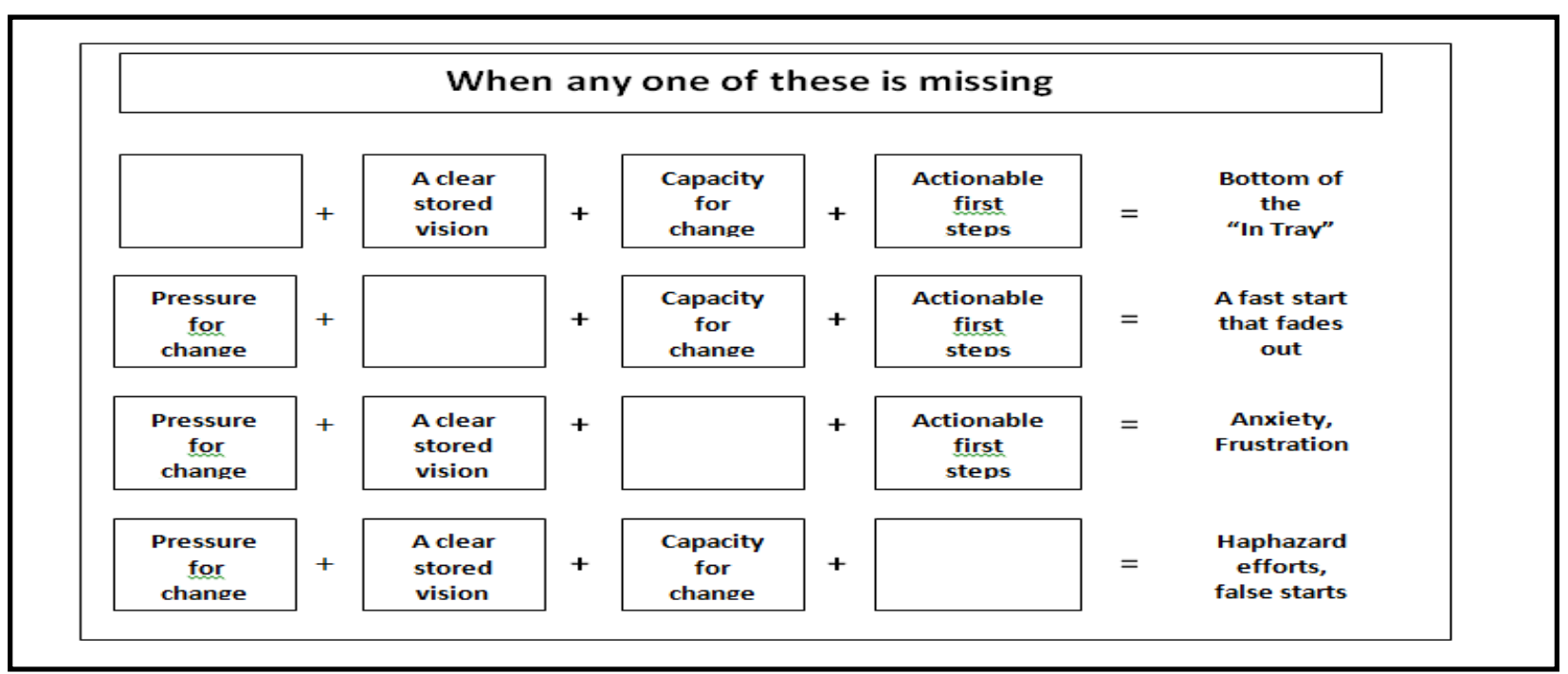

Figure 2b: Success factors for project implementation Source: Fregenti and Cominios (2012)

In 2008, NDDC appointed ACCENTURE-Nigeria to carry out a Repositioning of the Commission. They were also to assist in building the Project Management Capacity of the Commission and assure timely delivery of high impact infrastructural projects. However, road projects awarded by the Commission afterwards still suffer from abandonment and time overrun.

As at 2016, NDDC had a total project portfolio of above 8,355 with roads/bridges projects accounting for over 3,300 (Ekere, 2017), and only about 30 percent of these roads projects are completed. There is also the perception that schedule overrun experienced on road projects awarded by NDDC results in expensive litigations. Omatsuli (2014) posited that the Commission as at 2014 had about 400 Legal cases instituted against it by aggrieved stakeholder in nine states of the Niger Delta Region with huge financial repercussion on the Commission.

\subsection{Research Methodology}

Physical visits to project sites and desk-top project file assessment were conducted on some completed road projects awarded by NDDC. Time-lag data of 162 data sets were analysed to enable the conduct of time-series and, the development of a regression model.

\subsection{Data collection}

Data were collected on completed road projects awarded by NDDC in the Nine State making up the region. While a total of 340 completed road projects were studied only 162 of these projects were analysed for the following reasons: (i) many of the completed projects were not comprehensively documented (ii) states like Edo and Ondo have relatively small number of well documented completed projects of 10 and 6 respectively (iii) Cross River state has 20 well documented completed projects and approximately this number of projects were taken for the other six states; (iv) only completed projects valued above two hundred million Naira $(\mathrm{N} 200 \mathrm{~m})$ was considered for this study so that small and informal completed "road" projects like grading of roads, foot bridges, minor rehabilitation works, etc. were excluded. Table 1 below shows the distribution of completed road projects used for the studies. 
Table 1: Completed road projects awarded by NDDC in the Niger Delta Region of Nigeria

\begin{tabular}{|c|c|c|c|c|}
\hline $\mathrm{S} / \mathrm{N}$ & State & $\begin{array}{ll}\text { Completed road } \\
\text { projects }\end{array}$ & $\begin{array}{l}\text { Completed road projects with } \\
\text { complete documentation }\end{array}$ & Selected data sets \\
\hline 1 & Abia & 73 & 33 & 21 \\
\hline 2 & Akwa-Ibom & 109 & 42 & 21 \\
\hline 3 & Bayelsa & 78 & 34 & 21 \\
\hline 4 & Cross River & 46 & 20 & 20 \\
\hline 5 & Delta & 219 & 51 & 21 \\
\hline 6 & Edo & 46 & 10 & 10 \\
\hline 7 & Imo & 96 & 40 & 21 \\
\hline 8 & Ondo & 28 & 6 & 6 \\
\hline 9 & Rivers & 374 & 104 & 21 \\
\hline 10 & Regional & 12 & - & - \\
\hline 11 & Total & 1081 & 340 & 162 \\
\hline
\end{tabular}

\subsection{Results and Discussion}

\subsection{Time overrun}

Tables 2 and 3 show results of qualitative studies of some completed road projects awarded by NDDC. Table 2 show the numerical time-lag in weeks and Table 3 show the percentage time-lag in weeks.

Table 2: Grouping of time overrun of completed NDDC roads (above N200 million Naira)

\begin{tabular}{|c|c|c|c|c|c|c|c|c|c|c|}
\hline \multirow[t]{2}{*}{ State } & \multicolumn{10}{|c|}{ Time lag (weeks) } \\
\hline & 0 & $\begin{array}{l}\text { Less } \\
\text { than } 26\end{array}$ & $27-52$ & $53-104$ & $105-156$ & $157-208$ & $209-260$ & $261-312$ & $\begin{array}{l}\text { Above } \\
312\end{array}$ & Projects \\
\hline Abia & 5 & 2 & 4 & 6 & 3 & 0 & 0 & 0 & 1 & 21 \\
\hline $\begin{array}{l}\text { Akwa- } \\
\text { Ibom }\end{array}$ & 8 & 4 & 1 & 2 & 2 & 0 & 1 & 1 & 2 & 21 \\
\hline Bayelsa & 4 & 3 & 6 & 2 & 5 & 1 & 0 & 0 & 0 & 21 \\
\hline $\begin{array}{l}\text { Cross } \\
\text { River }\end{array}$ & 5 & 3 & 3 & 3 & 4 & 2 & 0 & 0 & 0 & 20 \\
\hline Delta & 5 & 5 & 2 & 4 & 4 & 0 & 0 & 0 & 1 & 21 \\
\hline Edo & 2 & 1 & 3 & 2 & 0 & 2 & 0 & 0 & 0 & 10 \\
\hline Imo & 10 & 0 & 3 & 4 & 3 & 1 & 0 & 0 & 0 & 21 \\
\hline Ondo & 0 & 1 & 1 & 2 & 1 & 0 & 0 & 1 & 0 & 6 \\
\hline Rivers & 8 & 2 & 1 & 5 & 4 & 0 & 0 & 1 & 0 & 21 \\
\hline Total & 47 & 21 & 24 & 30 & 26 & 6 & 1 & 3 & 4 & 162 \\
\hline
\end{tabular}

Table 3: Percentage of groups of time overrun of completed roads (above N200 million Naira)

\begin{tabular}{|c|c|c|c|c|c|c|c|c|c|c|}
\hline \multirow[t]{2}{*}{ State } & \multicolumn{9}{|c|}{ Time lag (\%) } & \multirow[b]{2}{*}{ Projects } \\
\hline & $0 \%$ & $\begin{array}{l}\text { Less than } \\
26 \%\end{array}$ & $\begin{array}{l}27- \\
52 \%\end{array}$ & $\begin{array}{l}53- \\
104 \%\end{array}$ & $\begin{array}{l}105- \\
156 \%\end{array}$ & $\begin{array}{l}157- \\
208 \%\end{array}$ & $\begin{array}{l}209- \\
260 \%\end{array}$ & $\begin{array}{l}261- \\
312 \%\end{array}$ & $\begin{array}{l}\text { Above } \\
312 \%\end{array}$ & \\
\hline Abia & 23.80 & 9.52 & 19.05 & 28.57 & 14.29 & 0 & 0 & 0 & 4.76 & 21 \\
\hline $\begin{array}{l}\text { Akwa- } \\
\text { Ibom }\end{array}$ & 38.10 & 19.05 & 4.76 & 9.52 & 9.52 & 0 & 4.76 & 4.76 & 9.52 & 21 \\
\hline Bayelsa & 19.05 & 14.29 & 28.57 & 9.52 & 23.81 & 4.76 & 0 & 0 & 0 & 21 \\
\hline $\begin{array}{l}\text { Cross } \\
\text { River }\end{array}$ & 25.00 & 15.00 & 15.00 & 15.00 & 20.00 & 10.00 & 0 & 0 & 0 & 20 \\
\hline Delta & 23.81 & 23.81 & 9.52 & 19.05 & 19.05 & 0 & 0 & 0 & 4.76 & 21 \\
\hline Edo & 20.00 & 10.00 & 30.00 & 20.00 & 0 & 20.00 & 0 & 0 & 0 & 10 \\
\hline Imo & 47.62 & 0 & 14.29 & 19.05 & 14.29 & 4.76 & 0 & 0 & 0 & 21 \\
\hline Ondo & 0 & 16.67 & 16.67 & 33.33 & 16.67 & 0 & 0 & 16.67 & 0 & 6 \\
\hline Rivers & 38.10 & 9.52 & 4.76 & 23.81 & 19.05 & 0 & 0 & 4.76 & 0 & 21 \\
\hline
\end{tabular}

Summary result based on a total of 162 completed road project is presented in Table 4. 
Table 4: Summary results of projects delayed/not delayed

\begin{tabular}{|c|c|c|c|}
\hline $\begin{array}{l}\text { No. of projects selected } \\
\text { states }\end{array}$ & Delay Periods & No. of projects delayed & Percentage of projects delayed \\
\hline \multirow{9}{*}{162 Awarded Projects } & No Delay & 47 & 29.01 \\
\hline & Less than 26 weeks & 21 & 12.96 \\
\hline & $27-52$ weeks & 24 & 14.81 \\
\hline & 53-104 weeks & 31 & 19.14 \\
\hline & 105-156 weeks & 26 & 16.15 \\
\hline & 157-208 weeks & 6 & 3.72 \\
\hline & 209-260 weeks & 1 & 0.62 \\
\hline & 261-312 weeks & 3 & 1.85 \\
\hline & Above 312 weeks & 4 & 2.47 \\
\hline
\end{tabular}

\subsection{Regression analysis of time series}

One independent and nine dependent variables were employed for this analysis. The selected independent and dependent variables and their codes are presented in Table 5.

Table 5: Independent and dependent variables of time lag data

\begin{tabular}{lll}
\hline S/N & Variables & Abbreviation \\
\hline 1 & 0 & $\mathrm{X}_{1}$ \\
2 & $<26$ & $\mathrm{X}_{2}$ \\
3 & $27-52$ & $\mathrm{X}_{3}$ \\
4 & $53-104$ & $\mathrm{X}_{4}$ \\
5 & $105-156$ & $\mathrm{X}_{5}$ \\
6 & $157-208$ & $\mathrm{X}_{6}$ \\
7 & $209-260$ & $\mathrm{X}_{7}$ \\
8 & $261-312$ & $\mathrm{X}_{8}$ \\
9 & $>312$ & $\mathrm{X}_{9}$ \\
10 & Total Projects & $\mathrm{Y}$ \\
\hline
\end{tabular}

To assess the dependence of the variables $\left(X_{1}, X_{2}, X_{3}, X_{4}, X_{5}, X_{6}, X_{7}, X_{8}, X_{9}\right)$ on the independent variable $(\mathrm{Y})$, regression analysis using the method of multiple regression was employed. An appropriate time series analysis of time overrun of completed NDDC roads is shown in Table 6.

Table 6: Time series analysis of time overrun of completed NDDC roads

\begin{tabular}{lllllllllll}
\hline States & $\mathrm{Y}$ & $\mathrm{X}_{1}$ & $\mathrm{X}_{2}$ & $\mathrm{X}_{3}$ & $\mathrm{X}_{4}$ & $\mathrm{X}_{5}$ & $\mathrm{X}_{6}$ & $\mathrm{X}_{7}$ & $\mathrm{X}_{8}$ & $\mathrm{X}_{9}$ \\
\hline Abia & 21 & 5 & 2 & 4 & 6 & 3 & 0 & 0 & 0 & 1 \\
Akwa-Ibom & 21 & 8 & 4 & 1 & 2 & 2 & 0 & 1 & 1 & 2 \\
Bayelsa & 21 & 4 & 3 & 6 & 2 & 5 & 1 & 0 & 0 & 0 \\
Cross River & 20 & 5 & 3 & 3 & 3 & 4 & 2 & 0 & 0 & 0 \\
Delta & 21 & 5 & 5 & 2 & 4 & 4 & 0 & 0 & 0 & 1 \\
Edo & 10 & 2 & 1 & 3 & 2 & 0 & 2 & 0 & 0 & 0 \\
Imo & 21 & 10 & 0 & 3 & 4 & 3 & 1 & 0 & 0 & 0 \\
Ondo & 6 & 0 & 1 & 1 & 2 & 1 & 0 & 0 & 1 & 0 \\
Rivers & 21 & 8 & 2 & 1 & 5 & 4 & 0 & 0 & 1 & 0 \\
\hline Total & 162 & 47 & 21 & 24 & 30 & 26 & 6 & 1 & 3 & 4 \\
\hline
\end{tabular}

\subsection{Assessment of normality}

For regression analysis, it is expected that the individual variables (dependent and independent) be approximately normally distributed. To test whether the variables are statistically normally distributed, the Jarque-Bera test for normality was employed. Mathematically, the Jarque-Bera test is defined as follows:

$J B=n\left[\frac{\left(\sqrt{b_{1}}\right)^{2}}{6}+\frac{\left(b_{2}-3\right)^{2}}{24}\right]$

where:

n sample size

$\sqrt{ } b_{1} \quad$ sample skewness and 


\section{$b_{2} \quad$ kurtosis coefficient}

The null hypothesis for the Jarque-Bera test is that the data is normally distributed while the alternate hypothesis is that the data does not come from a normal distribution. In which case;

$\mathrm{H}_{0}=$ Data follows a normally distributed

$\mathrm{H}_{1}=$ Data do not follow a normal distribution

In general, a large JB value indicates that the residuals are not normally distributed. A value of JB greater than 10 means that the null hypothesis has been rejected at the 5\% significance level. In other words, the data do not come from a normal distribution. JB value of between (0-10) indicates that data is normally distributed. For normality, the skewness coefficient should not be greater than 1 and the kurtosis should not be greater than 3.4. Also, the Jarque-Bera test value less than 10 and the (p-value) is greater than the 5\% significant value are indicative that the null hypothesis should be accepted, whereby, it could be concluded that the data follows a normal distribution. Result of the normality test for the variable $\mathrm{X}$ and $\mathrm{Y}$ are shown in Table 7.

Table 7: Results of normality test for variables $\mathrm{X}$ and $\mathrm{Y}$

\begin{tabular}{lllllll}
\hline S/No & Variables & $\begin{array}{l}\text { Skewness } \\
\text { Coefficient }\end{array}$ & $\begin{array}{l}\text { Kurtosis } \\
\text { value }\end{array}$ & $\begin{array}{l}\text { Jarque-Bera } \\
\text { Value }\end{array}$ & p-value & Normality Status \\
\hline 1 & $\mathrm{X}_{1}$ & -0.113335 & 2.2385 & 0.2385 & $88.76 \%$ & Normally distributed \\
2 & $\mathrm{X}_{2}$ & 0.223607 & 2.13000 & 0.358837 & $83.58 \%$ & Normally distributed \\
3 & $\mathrm{X}_{3}$ & 0.736612 & 2.7893 & 0.830329 & $66.02 \%$ & Normally distributed \\
4 & $\mathrm{X}_{4}$ & 0.576161 & 1.991481 & 0.886960 & $64.18 \%$ & Normally distributed \\
5 & $\mathrm{X}_{5}$ & -0.566391 & 2.216048 & 0.711665 & $70.06 \%$ & Normally distributed \\
6 & $\mathrm{X}_{6}$ & 0.680414 & 1.83333 & 1.204861 & $54.75 \%$ & Normally distributed \\
7 & $\mathrm{X}_{7}$ & 2.474874 & 7.125000 & 15.56836 & $0.04 \%$ & Not Normally distributed \\
8 & $\mathrm{X}_{8}$ & 0.707107 & 1.50000 & 1.593750 & $45.07 \%$ & Normally distributed \\
9 & $\mathrm{X}_{9}$ & 1.238006 & 3.170360 & 2.309870 & $31.51 \%$ & Not Normally distributed \\
10 & $\mathrm{Y}$ & -1.431427 & 3.2224 & 3.2224 & $21.31 \%$ & Normally distributed \\
\hline
\end{tabular}

\subsection{Residual probability plot}

To ascertain the suitability of regression method in explaining the dependence of the selected dependent variables on the independent variable, the residual probability plot was employed. To apply regression model, the residual probability plot must fluctuate around the linear mean value as presented in Figure 2.

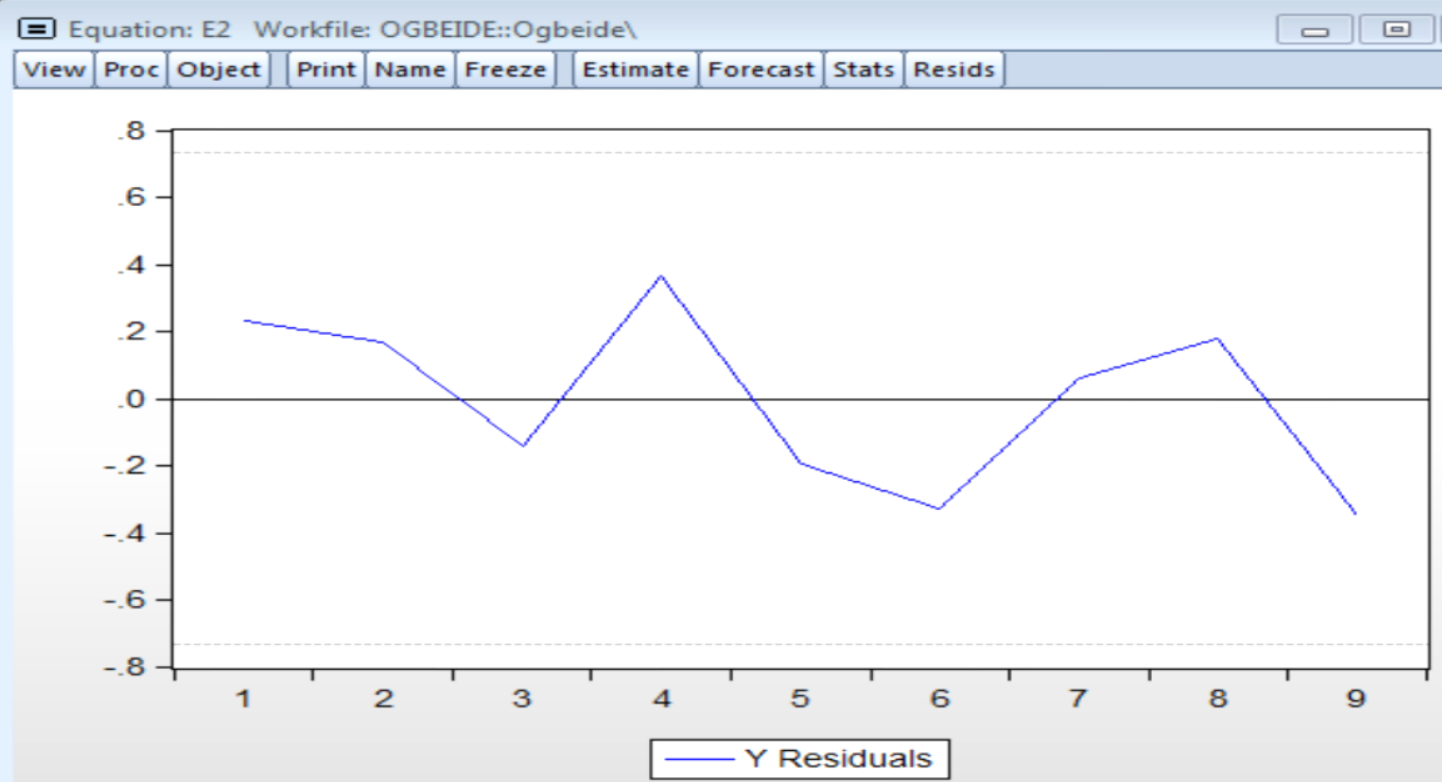

Figure 2: Residual probability plot 
Based on the result of Figure 2, it was concluded that multiple linear regression model is suitable for this analysis. In regression analysis of data, it is pertinent to note that standard error estimation and computation of $t$-statistics are appropriate in calculating the probability ( $p$-value) by which the significance of the regression model is tested. In the presence of heteroscedasticity, it is assumed that the overall standard error of regression and the t-statistics computed for each variable may not be completely adequate to estimate the resulting probability ( $p$-value) of regression. In addition, the presence of serial correlation can lead to a number of issues, namely; make reported standard error and t-statistics to be invalid, and coefficient may be biased, though not necessarily inconsistent. Based on this argument, selected diagnostic statistics were conducted to verify the statistical properties of the overall regression model. The selected diagnostic statistics include; heteroscedasticity test using Breusch-Pagan Godfrey, and Variance Inflation Factor (VIF).

\subsection{Heteroscedasticity test}

Heteroscedasticity is a diagnostic test statistics used to diagnose the adequacy of the probability (pvalue) calculated for each individual variable. Hence it is important to know whether there is or there is no heteroscedasticity in the data. The null and alternate hypothesis of heteroscedasticity was formulated as follows:

$\mathrm{H}_{0}=$ Presence of homoscedasticity and absence of heteroscedasticity

$\mathrm{H}_{1}=$ Absence of homoscedasticity and presence of heteroscedasticity

Result of heteroscedasticity using Breusch-Pagan Godfrey is presented in Table 8.

Table 8: Result of heteroscedasticity test

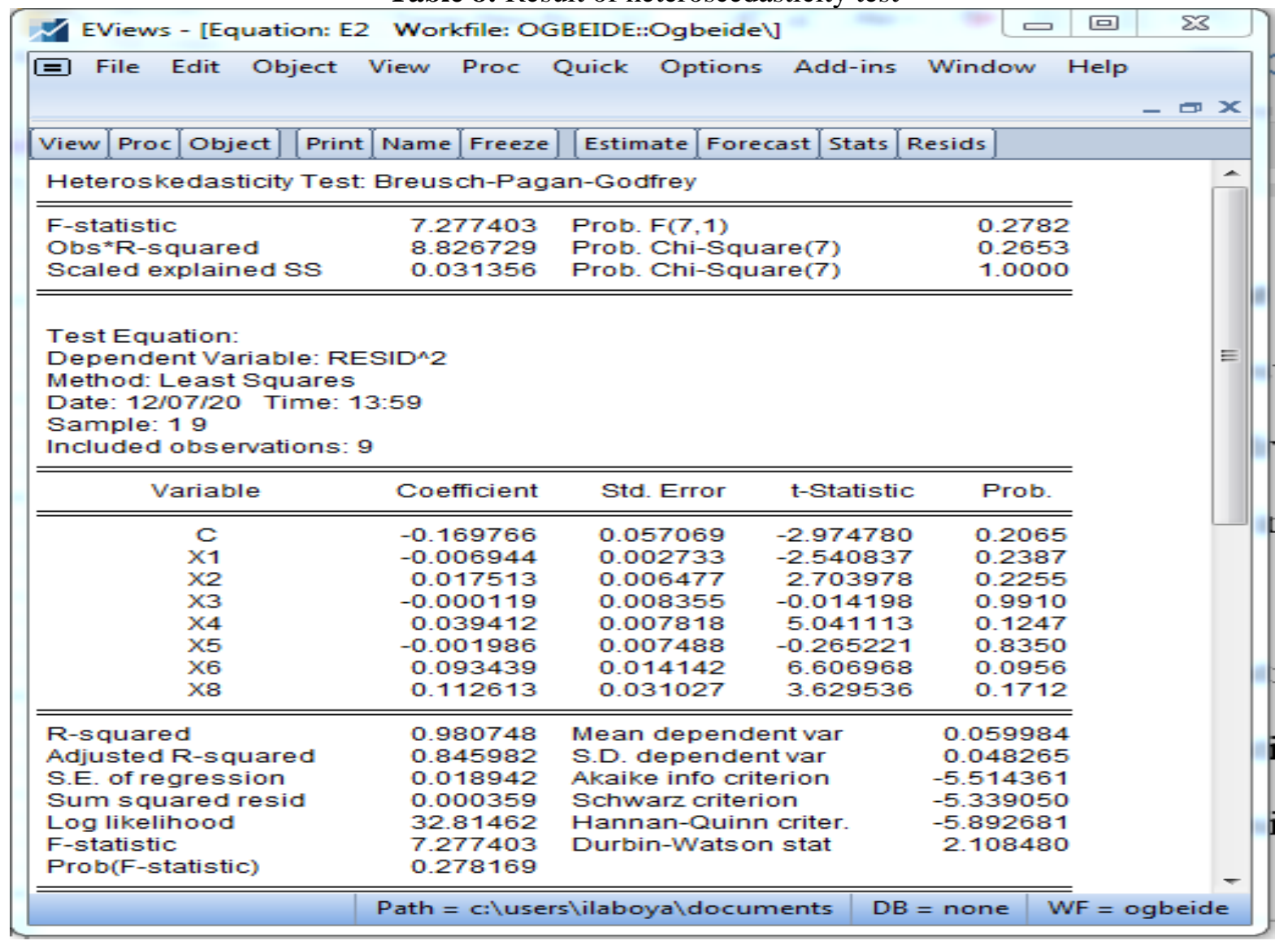

From the result of Table 8 it was observed that; the calculated ( $p$-value) based on the $F$-statistics is 0.2782 , and the calculated ( $p$-value) based on Lagrange multiplier (LM) is 0.2653 . Since the computed ( $p$-value) based on $F$-statistics and Lagrange multiplier are greater than $0.05(P>0.05)$, we accept the null hypothesis of homoscedasticity and conclude that there is no heteroscedasticity in the data. 


\subsection{Variance Inflation Factor (VIF)}

Variance inflation factor (VIF) measures the correlation of the dependent variables with the independent variable. Ideal VIF is 1; VIF greater than 10 is cause for alarm showing the variables are uncorrelated due to multicollinearity. Result of the calculated VIF for the selected variables is presented in Table 9.

Table 9: Calculated variance inflation factors

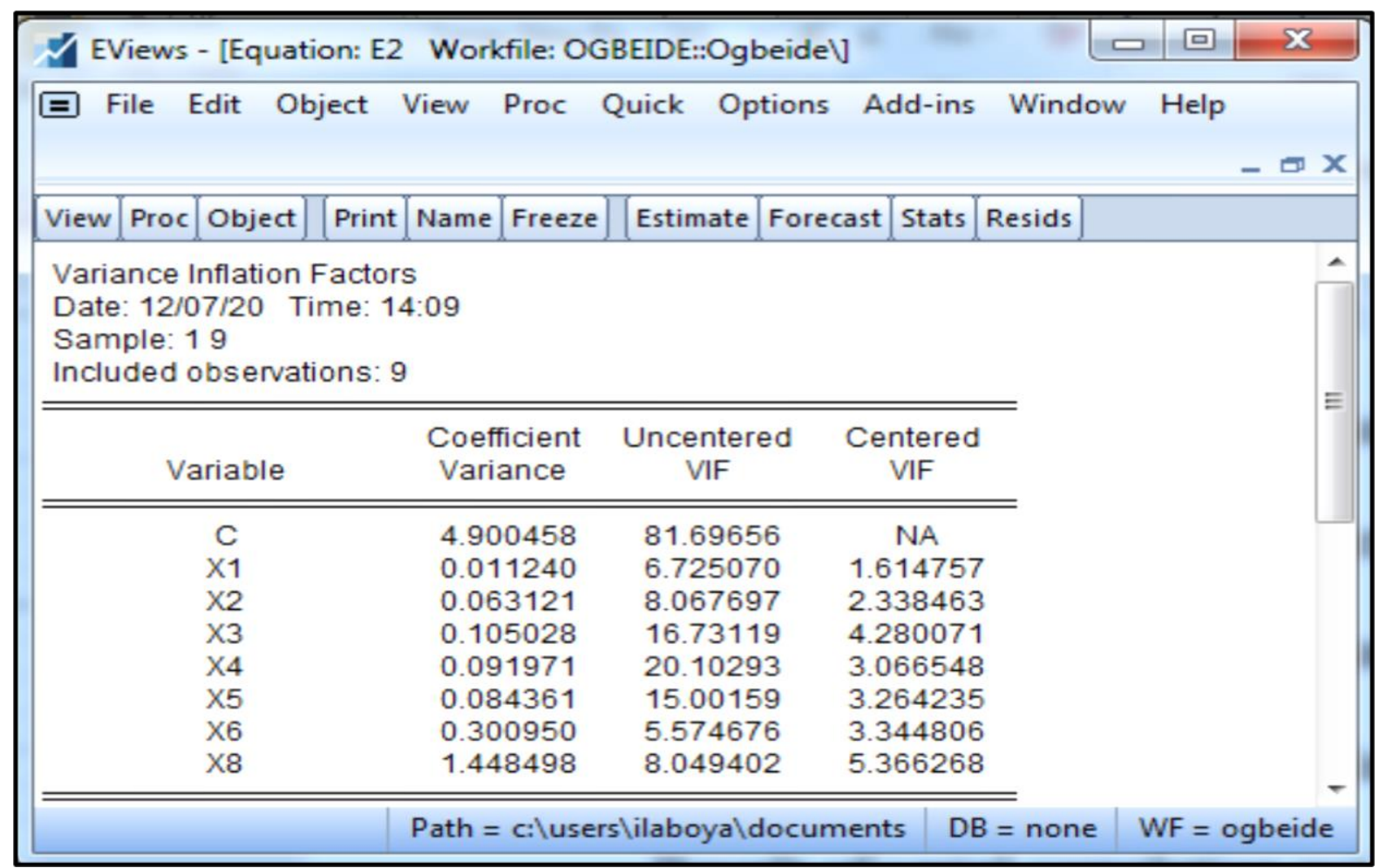

Since the computed variance inflation factors for the selected dependent variables are less than 10, it was concluded that the variables are well correlated with the independent variable, hence absence of multicollinearity. Finally, the dependence of the selected dependent variables on the independent variable was evaluated using the coded multiple regression equation function presented as:

$(Y)=C\left\{X_{1} X_{2} X_{3} X_{4} X_{5} X_{6} X_{8}\right\}$

Variable $X_{7}$ and $X_{9}$ were omitted since they are not normally distributed. The coded regression equation was implemented using Eviews and results obtained are presented in Table 10. 
Table 10: Output of regression analysis

\begin{tabular}{|c|c|c|c|c|c|c|c|c|c|c|}
\hline \multicolumn{10}{|c|}{ Đ Equation: E4 Workfile: OGBEIDE NEW::Untitled\ } & \multirow[t]{2}{*}{$\square \quad \square \quad x$} \\
\hline View & Proc & Object & Print] & Name & Freeze & Estimate & Forecast & Stats $\mathrm{R}$ & Resids & \\
\hline \multirow{5}{*}{\multicolumn{11}{|c|}{$\begin{array}{l}\text { Dependent Variable: } \mathrm{Y} \\
\text { Method: Least Squares } \\
\text { Date: } 12 / 07 / 20 \text { Time: } 15: 55 \\
\text { Sample: } 19 \\
\text { Included observations: } 9\end{array}$}} \\
\hline & & & & & & & & & & \\
\hline & & & & & & & & & & \\
\hline & & & & & & & & & & \\
\hline & & & & & & & & & & \\
\hline \multicolumn{4}{|c|}{ Variable } & \multicolumn{2}{|c|}{ Coefficient } & Std. Error & \multicolumn{2}{|c|}{ t-Statistic } & Prob. & \\
\hline & & $\mathrm{C}$ & & -1.19 & 97412 & 2.21369 & & 540911 & 0.6843 & \\
\hline & & $\mathrm{X} 1$ & & 1.22 & 27930 & 0.10601 & & 1.58214 & 0.0548 & \\
\hline & & $\mathrm{X} 2$ & & 1.61 & 16039 & 0.25124 & & 432265 & 0.0982 & \\
\hline & & $\mathrm{X} 3$ & & 1.36 & 60726 & 0.32408 & & 198738 & 0.1488 & \\
\hline & & $\mathrm{X} 4$ & & 1.02 & 20601 & 0.30326 & & 365344 & 0.1839 & \\
\hline & & $\mathrm{X} 5$ & & 0.34 & 41867 & 0.29045 & & 177027 & 0.4483 & \\
\hline & & $\mathrm{X} 6$ & & 0.66 & 65128 & 0.54859 & & 212433 & 0.4391 & \\
\hline & & $\mathrm{X} 8$ & & 1.65 & 57477 & 1.20353 & & 377173 & 0.3998 & \\
\hline \multicolumn{4}{|c|}{ R-squared } & \multicolumn{2}{|c|}{0.997970} & \multicolumn{3}{|c|}{ Mean dependent var } & 18.00000 & \\
\hline \multicolumn{4}{|c|}{ Adjusted R-squared } & \multicolumn{2}{|c|}{0.983764} & \multicolumn{3}{|c|}{ S.D. dependent var } & 5.766281 & \\
\hline \multirow{2}{*}{\multicolumn{4}{|c|}{$\begin{array}{l}\text { S.E. of regression } \\
\text { Sum squared resid }\end{array}$}} & \multicolumn{2}{|c|}{0.734747} & \multicolumn{3}{|c|}{ Akaike info criterion } & 1.801972 & \\
\hline & & & & \multicolumn{2}{|c|}{0.539853} & \multicolumn{3}{|c|}{ Schwarz criterion } & 1.977282 & \\
\hline \multicolumn{4}{|c|}{ Log likelihood } & \multicolumn{2}{|c|}{-0.108872} & \multicolumn{3}{|c|}{ Hannan-Quinn criter. } & 1.423652 & \\
\hline \multicolumn{4}{|c|}{ F-statistic } & \multirow{2}{*}{\multicolumn{2}{|c|}{$\begin{array}{l}70.24670 \\
0.091620\end{array}$}} & \multirow{2}{*}{\multicolumn{3}{|c|}{ Durbin-Watson stat }} & 2.108480 & \\
\hline \multicolumn{4}{|c|}{ Prob(F-statistic) } & & & & & & & \\
\hline
\end{tabular}

From the result of Table 10, the following observations were made: since the adjusted R-square value of 0.983764 is in reasonable agreement with the observed coefficient of determination $\mathrm{R}^{2}$ value of 0.997970 , it was concluded that the regression model was reasonably adequate. Using the result of Table 10, the overall regression equation was thereafter generated and presented as follows:

$$
\begin{aligned}
Y=-1.1974+ & 1.2279 X_{1}+1.6160 X_{2}+1.3607 X_{3}+1.0206 X_{4}+0.3419 X_{5}+0.6651 X_{6} \\
+ & 1.6575 X_{8}
\end{aligned}
$$

\subsection{Conclusions}

This study shows that NDDC's completed road projects experiences time overrun as indicated below:

- $29.01 \%$ of the awarded projects were completely executed within the required duration without delay

- $12.96 \%$ of the projects experienced between 1-26 weeks' delay before final completion

- $14.81 \%$ of the projects experienced between 27-52 weeks' delay before final completion

- $19.14 \%$ of the projects experienced between 53-104 weeks' delay before final completion

- $16.15 \%$ of the projects experienced between 105-156 weeks' delay before final completion

- $3.72 \%$ of the projects experienced between 157-208 weeks' delay before final completion

- $0.62 \%$ of the projects experienced between 209-260 weeks' delay before final completion

- $1.85 \%$ of the projects experienced between 261-312 weeks' delay before final completion

- $2.47 \%$ of the projects experienced above 312 weeks' delay before final completion

- A conceptual model of time series with Number of Awarded Projects as dependent variables $(\mathrm{Y})$ and Lengths of Construction delay as the independent variable $(\mathrm{X})$ was developed as: $\mathrm{Y}=-1.1974+1.2279 \mathrm{X}_{1}+1.6160 \mathrm{X}_{2}+1.3607 \mathrm{X}_{3}+1.0206 \mathrm{X}_{4}+0.3417 \mathrm{X}_{5}+0.6651 \mathrm{X}_{6}$ $+1.6575 \mathrm{X}_{8}$

Based on the findings, the following recommendations were made:

- NDDC should evolve technologies to document and keep records of her project delivery portfolio. This will enable access to more reliable data for further studies.

- The Commission should also deploy technologies to minimize construction delay on her road projects. 


\section{References}

Chai, C. S., Yusaf, A. M. and Habil, H. (2015). Delay mitigation in the Malaysian housing industry: A structural equation modelling approach. Journal of construction in developing Countries, 20(1), pp. $65-83$.

Duerkop, S. and Hurt, M. (2017). Transportation under threats-A PESTLE analysis for critical logistical infrastructure, Paper presented at the 2017 AGM \& Annual conference of the Nigerian Institution of Highway and Transportation Engineer, Abuja, Nigeria, $7^{\text {th }}$ Dec, 2017.

Ekere, E. (2017). We must have standards below which we cannot go, An address by the MD/CEO of NDDC to NDDC Consultants and Contractors on September 28, 2017, Presidential Hotel, Port Harcourt.

Fregenti, E. and Cominios, D. (2012). Practice of project management - a guide to the business focused approval, Kogan Rolge Publishers.

Khan, L. (2015). Causes of delays in construction projects and their effects" (available at https.//engrligmankhan.wordpress.com), pp. 1/38-36/38.

Kikwasi, G. J. (2012). Causes and effects of delays and disruptions in construction projects in Tanzania. Australian Journal of Construction Economics and Building Conference, (2), pp 52-59.

Kolhe, R. and Darade, M. (2014). Detail analysis of delay in construction projects. International Journal of Innovative Science, Engineering \& Technology, 1(10), pp. 70-72.

Lo, T. Y., Fung, I. W. H. and Tung, K. C. F. (2006). Construction delay in Hong Kong Civil Engineering Projects. Journal of Construction Engineering and Management, 132(6), pp. 636-649.

Memon, A. H., Rahman, I. A., Akram, M. and Ali, N. M. (2014). Significant factors causing time overrun in construction projects of Peninsular Malaysia. Journal of Modern Applied Science, 8(4), pp. $16-28$

Mohamad, M. R. B. (2010). The factors and effect of delay in government construction project, case study in Kuantan University, Malaysia, Patiang.

Omatsuli, T. (2014). Sustainable Project Management, A paper delivered at the 2014 NDDC Board and Management Retreat, March 12-13, Le Meridian Hotel, Uyo, Nigeria.

Owolabi, J. D., Amusan, L. M., Oloke, C. O., Tunji- Olayemi, P., Owolabi, D., Peter, J. and Omuh, I. (2014). Causes and effect of delay of project construction delivery time. International Journal of Education and Research, 2(4), pp. $197-208$.

Pall, G. K., Bridge, A. J., Skitmore, M. and Gray, J. (2016). Comprehensive Review of Delays in Power Transmission Projects. Inst. Eng. Technol., 10(14), pp. 3393-3404.

Pickavance, K. (2010). Delay and disruption in construction contracts. $4^{\text {th }}$ Edition, Sweet $\&$ Mawell, London, UK

Ramli, M. Z., Malek, M. A., Muda, M. Z., Talib, Z. A., Azman, N. S., Fu'ad, N. F. S. M., Zawawi, M. H. and Katman, Y. (2018). A review of Structural Equation Model for Construction Delay Study. International Journal of Engineering \& Technology, 7, pp. 299-306.

\section{Cite this article as:}

Ogbeide F. N., Ehiorobo J. O., Izinyon O. C. and Ilaboya I. R. 2021. A Qualitative Study of Time Overrun of Completed Road Projects Awarded by the Niger Delta Development Commission in the Niger Delta Region of Nigeria. Nigerian Journal of Environmental Sciences and Technology, 5(1), pp. 271-280. https://doi.org/10.36263/nijest.2021.01.0269 